\title{
From Folk Tale to Photomontage: A Transformation through a Stage Performance
}

\author{
Rikard Hoogland
}

\begin{abstract}
A photomontage from I 894-95 with material from the popular and successful theatre production Ljungby horn is the artefact in this chapter. The photomontage is connecting with the development of theatre photography, which was governed by the commercial market for visiting cards. The term remediation is used to describe a transformation whereby the different sources are, through the use of photography, placed on the same level in the montage. Other intermedial connections discussed here include music, literature, communications, theatre set design, and mass media.
\end{abstract}

A large photo was found in a file at the National Library of Sweden in Stockholm containing correspondence between Albert Ranft and Frans Hodell (Figure I), ${ }^{\mathrm{I}}$ including a letter written by the theatre manager to Hodell, an author, editor-in-chief, and actor. The letter, dated I884, relates that Ranft has taken over the management of one of Sweden's most prominent touring theatre companies as one of the first steps towards building his large theatre empire. Ranft seems to be asking for some positive news items about the company, probably in the popular illustrated

I Albert Ranft in a letter to Frans Hodell, Kempes autografsamling (Kempe's collection of autographs) in Kungliga biblioteket (National Library of Sweden), KBI/I3.

How to cite this book chapter:

Hoogland, Rikard. "From Folk Tale to Photomontage: A Transformation through a Stage Performance." In The Power of the In-Between: Intermediality as a Tool for Aesthetic Analysis and Critical Reflection, edited by Sonya Petersson, Christer Johansson, Magdalena Holdar, and Sara Callahan, I29-I47. Stockholm: Stockholm University Press, 20I8. DOI: https://doi. org/IO.I6993/baq.f. License: CC-BY. 


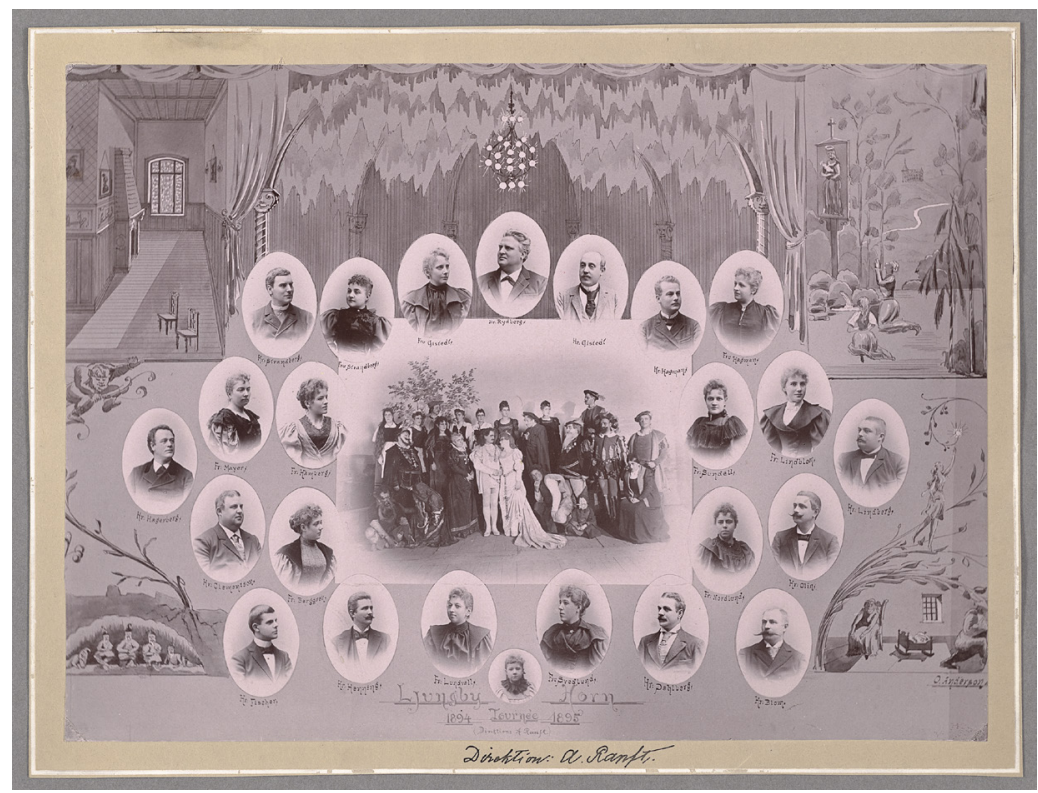

Figure 1. Ljungby horn tournée, I 894-95. Reproduction: National Library of Sweden/Kungliga biblioteket, Stockholm. License: CC-BY-NC-ND.

magazine Söndags Nisse, of which Hodell was editor and owner. ${ }^{2}$ The photo, however, is from an I 894-95 tour with the melodramatic fairy-tale-based play Ljungby horn, so there is no direct connection between the letter and the photo apart from the name Albert Ranft. In this article, I study the picture as an artefact and look not only into its connections to the production but also into connections between media systems of that time and the theatre deriving from this specific photo. The photo can be seen as a form of mediatization of the theatre performance, but may also be used as a link to a performance to which we have no direct connection. In the chapter, the use of theatre photography in the late nineteenth century is described, and the relation between the studio portraits of the actors and the live performance is discussed. I will use the theoretical concept of remediation for analyzing the

2 Oscar Wieselgren, "Frans O. L. Hodell," Svenskt biografiskt lexikon, accessed October 28, 20I6, https://sok.riksarkivet.se/sbl/artikel/ı3680. 
artefact and the different layers in the collage and their relations to the live performance.

The first questions that arise are why the photo was made and what function it could have had. Could it be that the image was sent to the magazine Söndags Nisse for publication? The fact that at that time the journal published only sketches and drawings, not reproductions of photos would seem to be evidence against this possibility. Or was it an act of gratitude for the support the magazine had given the production when it ran in Stockholm during the summer of I 894? Or was it a gift that was circulated on a larger scale by Ranft to important individuals in the media industry? The fact that the picture has not yet been found in any other archive would be an argument against this possibility.

The production of the fairy-tale-based play Ljungby horn was a big success for Albert Ranft; after a sold-out premiere at Stora Teatern in Gothenburg, it proceeded to Malmö Teater; a special train service was arranged all around Scania and in Stockholm, where it was staged at Djurgårdsteatern. The photomontage is made for the national and Nordic tour that started in the autumn of I 894, following seventy performances in Stockholm. Nearly all of the actors playing the main parts in the play were replaced by new actors for the tour. Even though several popular actors were no longer part of the production, the performances were still successful, and over 300 performances had been given when the tour ended in Trondheim in May I895.

\section{Photomontage}

In taking a closer look at the photograph, one sees that it is clearly a photo of a montage consisting of four different parts. The photo is not large: about $24.7 \times 18.6 \mathrm{~cm}$, that is, larger than a postcard but smaller than an ordinary piece of foolscap. It has some resemblance to private albums of the time, with the difference that it is associated with a theatre manager rather than a private person. Anna Dahlgren, in her study of photo albums, has included an example bearing a slight visual resemblance to the Ljungby horn example: a collection of photos from visiting cards depicting actors from a production at the Dramatic Theatre in Stockholm 
I 867. The photos show the actors in their stage costumes, with the individual photos arranged in a semicircle like a fan. Text about the performance of Min ros $i$ skogen taken from the theatre's daily poster is pasted in the lower part of the arrangement. ${ }^{3}$ Dahlgren's source is the archive of Nordiska museet, but there is no consensus on who was responsible for its composition or whether it is the same person as the unknown owner of the album. However, the composition does not look as if it had been made for a commercial market; rather, it resembles a privately organized album page for remembering a specific theatre evening. Dahlgren also writes about the album as something that might be placed in a private drawing room, where guests could look through it. The album might, in this example, lend the owner cultural value and lead to conversations about the theatre and actors in Stockholm, and the room might be described as a semi-private and public space. ${ }^{4}$ The visiting-card photos included in the montage from I 867 demonstrate a more professional touch compared with an amateurish collage, and were clearly made for commercial distribution (I will return later to the question of the market for theatre photographs). There are also other examples from I 860 of montages of actors' visiting-card photos. Mosaic pictures made from visiting-card photos was cut out and pasted in formation on a large piece of paper and afterwards photographed to fit the visiting-card format. ${ }^{5}$

At the time (in either I 894 or I 895 ) the montage was made for Ljungby horn, the development of photography had created new possibilities not yet available in 1867 , especially in terms of flash-lighting techniques. There are several photos taken of the actors in their costumes from Ljungby horn, and even photos showing two actors. It is uncertain whether the photos were taken in the photographer's studio or on stage. The photos

3 Anna Dahlgren, Ett medium för visuell bildning: Kulturhistoriska perspektiv på fotoalbum I 850-I950 (Stockholm: Makadam, 20I3), 37.

${ }_{4}$ Christopher B. Balme, The Theatrical Public Sphere (Cambridge: Cambridge University Press, 2013).

5 Rolf Söderberg and Pär Rittsel, Den svenska fotografins historia I840-I940 (Stockholm: Bonnier Fakta, I983), 44-45. 


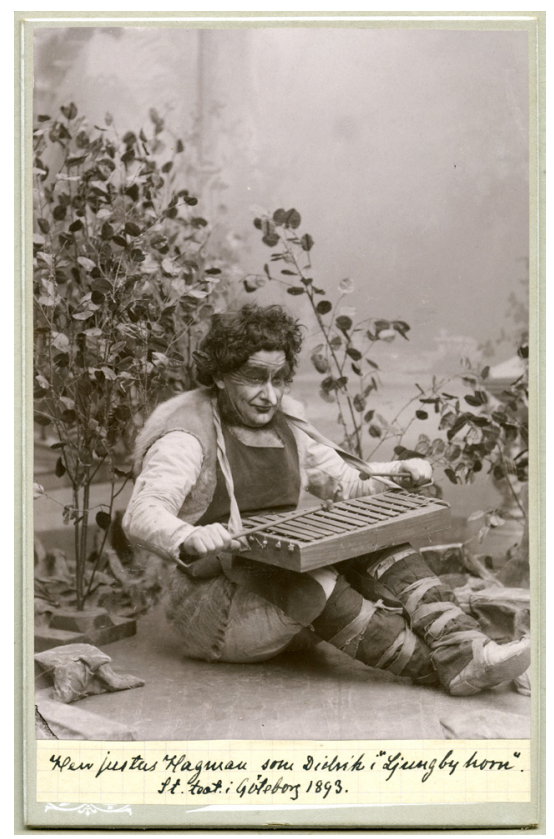

Figure 2. Justus Hagman in Ljungby horn, Stora Teatern in Gothenburg I 893, photographed by Alfred Peterson. Permission: Swedish Performing Arts Agency/Statens musikverk, Stockholm. License: CC-PD. Available at Wikimedia Commons: https://commons.wikimedia.org/wiki/File:Justus_ Hagman,_rollportr\% $\mathrm{C}_{3} \% \mathrm{~A}_{4} \mathrm{tt}_{-}-\mathrm{SMV}_{-}$-_H9_I 88. tif.

taken in Stockholm by Gösta Florman in I 894 were more likely taken in front of the backdrop from the production. Florman, who had moved his atelier from Karlstad to Stockholm, was at that time the most celebrated theatre photographer in Sweden. ${ }^{6}$ The photos from Gothenburg I 893 look more like photos taken in the atelier, but the photo of the dwarf and hobgoblin Didrik, played by Justus Hagman, includes props such as bushes and small trees that could have been used in performances (Figure 2). No backdrops or costumes from the production have been preserved. In the archive in Gothenburg, some coloured

${ }^{6}$ Söderberg and Rittsel, Den svenska fotografins historia, $5 \mathrm{I}$. 
costume drawings have been collected, showing us the colour scheme of the costumes, which is impossible to guess from the black-and-white photos. ${ }^{7}$

\section{Multilayer}

The montage is a collection of several layers from various art forms-ensemble photos, portrait photos, sketches, and handwritten text. The original montage has not been saved; the archival item is a photo of the montage that was pasted onto a carton and thereafter inscribed "Direktion A. Ranft" on the lower part of the carton framing the photo. Albert Ranft was the manager and director, who, with the help of this production, was able to ensure the start of his large theatre company.

I am now going to describe the layers of the montage. In the center is a group portrait of the ensemble in stage dress, surrounded by portraits of the actors in street dress; under the portraits, the actors' family names and civil titles are written. In the outer circle are sketches, probably of the set design and impressions from the stage. There is a signature in the bottom-right corner: "O Anderson," the name of the painter; the owner of the workshop that produced the backdrops for the performance was Carl Grabow of Stockholm. Text in the lower central part reads: "Ljungby Horn, Tournée I 894-I895, (direktion A. Ranft.).” The montage seems to have been arranged on a carton that was then photographed.

Could the original montage been larger than the one found in the archive? This raises questions about the purpose for which such a montage was arranged: was it made for marketing purposes, or as a souvenir? Was the original montage larger, for placement in a display cabinet outside the theatre? I have not seen any examples of such photos being put on display at the theatres at that time.

The relationship between written text and visual pictures during the late nineteenth century has been debated in the field of cultural history. As Aleida Assmann points out, "[t]he textual

7 Costume sketch Ljungby horn, Göteborgs stadsmuseum (The Museum of Gothenburg), GTM2 г 20. 
tradition was one of clarity and light, and that of pictures and traces was dark and enigmatic [...] The two media were in fact seen as incommensurate, each untranslatable into the other and yet at the same time stimulating acts of translation." ${ }^{8}$ Traditionally, written sources have been seen as more reliable than visual; this attitude is still common.

\section{The Play Script}

One source that could be combined with visual elements is the play script, a free translation from Danish by the playwright Frans Hedberg. The original, entitled Et Folkesagn, was a successful play running at Folketeatret in Copenhagen in the spring of I 893 , based on a popular ballet by August Bournonville, which had premiered at the same theatre in I $854 .{ }^{9}$ If we can believe his memoirs, Albert Ranft had already pointed out in his commission to Hedberg how the script should be adapted to create a play about the old legend of the Ljungby horn and pipe. ${ }^{1 \circ}$ Ranft, along with the actor Anders de Wahl, visited Folketeatret in Copenhagen in the course of a stop by the touring company in Malmö in January I 893. Subsequently, de Wahl starred in the performance as the knight Olof. The most important change that had to be made, as far as Ranft was concerned, was that the performance should start with the singing of the popular ballad about the Ljungby horn and pipe. ${ }^{I I}$ The resemblance to the legend was repeated in reviews and news items, though nobody seemed eager to point out that very few details were in accord with the "original story." Bournonville himself had based his story on a recently published collection of fairy tales collected by Just M. Thieles and on the short story "Everhøj" written by Hans Christian Andersen, so it was a combination of different folk tales that laid the ground for

${ }^{8}$ Aleida Assmann, Cultural Memory and Western Civilization (Cambridge and New York: Cambridge University Press, 2013), 208.

9 Knut Arne Jürgensen, The Bournonville Tradition: The First Fifty Years, I 829-I879 (London: Dance Books, I997), I67.

ז Albert Ranft, Albert Ranfts memoarer: Första delen (Stockholm: Norstedts, I928), I34.

ir Ballad by Frans Friberg and Lorenzo Hammarsköld, I 8I 3 . 
the production. ${ }^{\mathrm{I} 2}$ The re-use of folk tales is a very common phenomenon in the development of popular theatre. As the researcher Joel Schechter states, "[p]opular theatre forms lend themselves to adaption, reinterpretation and changes of content because they originate in unwritten and improvised performance traditions." ${ }^{\text {I3 }}$ Bournonville also obtained an agreement to produce the ballet in Stockholm in I 859 , but it was never realized. ${ }^{\mathrm{I} 4}$ Moreover, the music composed for Bournonville's performance by N. W. Gade and P. E. Hartmann was re-used, not only in the play Et Folkesagn, but in other plays and as a popular wedding song as well.

The play runs 243 handwritten pages and places the story in northern Scania around the castle Ljungby at the beginning of the seventeenth century. ${ }^{15}$ The main point of the story is that hobgoblins have exchanged children in the cradle. The daughter, Hildur, was replaced in the castle with Birgit, who does not meet feminine norms and who has a bad temper, drinks excessively, and wants to dance at night. It is decided that the "false" daughter should be married to the knight Olof, but he refuses. Hildur, who is held prisoner in the underworld, is to be married to her "brother" Vidrik, who is 300 years older. She escapes with the help of her other "brother," Didrik, and decides to stay in the upper world and finally to marry Olof. When she decides not to return, the underworld collapses and all of its inhabitants have to leave the forest to find a new place to settle. Birgit is married to an old farmer attracted to such dissolute women, and as punishment he is obliged to act as her servant.

I2 Svend Kragh-Jacobsen, "August Bournonville og den romantiske ballet," in Den kongelige danske ballet, eds. Svend Kragh-Jacobsen and Torben Krogh (Copenhagen: Selskabet till udgivelse af kulturskrifter, I952), 77.

I3 Joel Schechter, ed., "Back to the Popular Source: Introduction to Part I," in Popular Theatre: A Sourcebook (London and New York: Routledge, 2003), Io.

${ }^{14}$ Jürgensen, The Bournonville Tradition, 167.

${ }^{15}$ Ljungby horn, play script, Svenska teatern in Helsingfors, Archive of Svenska teatern, Svenska litterära sällskapet (Society of Swedish Literature in Finland), Helsingfors. 


\section{Theatre Photographs}

The layers of the photo require a more specific description for analysis, starting with the ensemble photo: in the center is the knight Olof, with Hildur, who was saved from the underworld. Their clothing features bright colours which contrast with other, darker colours. On the right side of the photo are men of importance, such as landowners, judges, etc. On the left, next to Hildur, is her mother, who rescued her from being condemned as a witch. Next to her stands Birgit, who had replaced Hildur and who represents a threat to the marriage of Hildur and Olof. In the upper row on the left are women dressed to serve male society as wives or servants. The women to the upper right are probably from the underworld, and at the bottom are gremlins and other dark forces.

In looking through the costume sketches, it becomes clear that the dark colours are red, blue, and green. Also, a handcoloured photo of Birgit indicates a dark green dress with red puffed sleeves. ${ }^{16}$ The dress and her little bag also feature decorations with golden embroidery. The men of importance are variously dressed, with decorations such as chains and multicoloured costume items. The photo does not depict the entire ensemble, but all of the most important parts are represented. There is also a difference in performative aspects; it is not clear who are in character during the photo session.

This leads to the question of the status of theatre photographs at the end of the nineteenth century. Jens Ruchatz has written in an article about the intermediality of theatre photography, dividing theatre photographs into pose and moment photos. A pose is characterized by lifelessness, whereas a moment tries to capture a performative aspect. ${ }^{17}$ Laurence Senelick discusses one

${ }^{16}$ Constance Gottschalk as Birgit in Ljungby horn, hand-coloured photo I893, Göteborgs stadsmuseum (The Museum of Gothenburg), GTM4743:I.

${ }^{17}$ Jens Rutchatz, "Zeit de Theaters/Zeit der Fotografie: Intermediale verschränkungen" in Theater und Medien: Grundlagen - Analysen Perspektiven: Eine Bestandsaufnahme, eds. Henri Schoenmakers et al. (Bielefeld: Transcript, 2008). 
of the first published books (I 859 ) on theatre to be illustrated with photos, about the actress Rachel. The criterion of her acting was her ability to "[fall] into graceful or expressive poses," which was seen as a standard for acting, and the photo book could be used for instruction. ${ }^{18}$ But as early as 1865 there were examples of photos that followed an acting sequence using a series of photos. However, all of the examples Senelick cites seem to be atelier photographs, not taken on the stage. He shows that the sequence photographs were widely dispersed in terms of geography, with examples from France, England, and Russia, but he offers no description about how they were received by the market.

Joel Anderson, in his book about theatre photography, comments upon the relation between the studio photo and the stage performance. The action captured on the photos is performed primarily for the photo occasion. "There are connections with actual stage practice: scenery might be sourced from theatre." ${ }^{19}$

The interesting thing in this ensemble photo from Ljungby horn is that the actors wear expressions that differ from one another and which relate more or less to their parts. The couple in the central position communicates love and belief, and their eyes are focused exclusively on each other. Almost everyone in the middle row is focusing on the couple. The three nearest all have different attitudes. The judge to the right seems content with rendering a correct judgement so the couple can get married; he holds his hands as if performing a judgement. Hildur's mother, to the left, also seems satisfied and is performing playing a protective mother. Next to her stands the enemy, Birgit, who glares angrily at the couple.

The actors in the upper row are not clearly focusing on the couple, nor is there any contact between them. The gremlins at bottom are performing chiefly for the audience/viewer. Only Justus Hagman, as Didrik, can be recognized.

\footnotetext{
I8 Laurence Senelick, "Early Photographic Attempts to Record Performance Sequence," Theatre Research International 22:3 (I997): 256.

19 Joel Anderson, Theatre and Photography (Basingstoke: Palgrave Macmillan, $2015), 43$.
} 
The backdrop is partly visible; on the left side, a tree is painted, and at the bottom it is possible to catch a glimpse of a wide landscape. Whether or not the backdrop in the photo was made for the performance is hard to determine, but the floor looks like a stage floor. The decorations made by Carl Grabow, the foremost theatre painter in Sweden, were presented in advertisements and on posters, and a total of six new decorations/ set designs were made for the production. Significantly, all of the decorations were freshly made, and no older decorations were re-used. ${ }^{20} \mathrm{I}$ have not seen any other example from that period where all scenery is listed in advertisements. It is possible that Ranft introduced an international trend here. The critics were astonished by the spectacular quality of the staging and the decorations; they also pointed out the use of effects. After the first night, a reviewer wrote: "No costs have been spared on this new production. Six new decorations, all with a great deal of atmosphere and beauty, painted by Carl Grabow, velvet and silk, beautiful maids and many expensive and peculiar props." ${ }^{21}$ He then cites more examples and closes by saying that this exceeds the expectations and fantasies of the readers, who need to go and see it. Grabow's studio in Stockholm was central to Swedish theatre society and produced set designs for all the important theatres. ${ }^{22}$ Some of these sets had to be transported to theatres; even Svenska Teatern in Helsinki used Grabow's services. In the case of touring companies, the expanding railway system made it more feasible to tour with several complete productions, thus changing the way the repertoire was put together. ${ }^{23}$

${ }^{20}$ Advertisement, Göteborgs-Posten, May I I, I 893.

${ }^{21}$ G. B. [signed], “Stora Teatern,” Göteborgs-Posten, May I I, I893. My translation.

22 Gösta M. Bergman, Den moderna teaterns genombrott I890-I925 (Stockholm: Bonniers, I966), 268.

${ }_{23}$ Claes Rosenqvist, Mittsvenska scener: Härnösand, Sundsvall och det sena I800-talets landsortsteater (Umeå: Johan Nordlander-sällskapet, I998), $233-234$. 


\section{Flash Lighting}

In the ensemble photo the use of the flash light is visible. In Söderberg and Rittsel's book about the Swedish photography's history they take up the development of flash light in the theatre. In I 89I the Swedish journal Fotografisk tidskrift informed readers about the possibility of taking indoor photos inside theatres and the same year a theatre in Copenhagen made some photos with actors standing in frozen positions on stage. They have traced a possible first Swedish example to the Royal opera in Stockholm I 894. They used magnesium flash light and the light sources were placed both in the auditorium and on the stage between the flats. During a ten-year period, the photographer Axel Rydin started to make documentations of the theatre performances in Stockholm. The problem with the photos was that they could not capture the theatrical atmosphere in the picture, and they were seen as impersonal. ${ }^{24}$ This is obvious when looking at the ensemble picture from Ljungby horn, in which parts have been overexposed, the background is not really visible, and the shadows of two of the actors are visible on the backdrop. Probably the photographer experimented with only one strong flash. The photo also lacked a director who might have better integrated the back row into the picture, so that its constituents would not look, as they do now, as though they are gazing indifferently in various directions. But there is no unwanted motion in the picture, so the group must have been disciplined.

The next layer of the montage is a circle with portraits of the actors in street dress, with their family names written under each photo. It is hard to analyze the actors' status in society from their clothing. The family names inform us that there are probably three married couples on tour: the Gistedts, Strandbergs, and Hagmans. All of the other females, except for Mrs Svedberg, bear the title Miss. Many of the touring companies fostered theatre families, whose children often travelled with the company. Here as well, a difference could be seen after the implementation of the railway system, making it possible to go away for shorter periods

${ }_{24}$ Söderberg and Rittsel, Den svenska fotografins historia, I 62. 
and thus still maintain contact with life in Stockholm. ${ }^{25}$ But there were also several actresses who remained unmarried. The theatre was an opportunity for women to earn an income and have an independent life. However, at that time their reputation outside the theatre world was questionable. The overwhelming majority of the pictures are taken partly in profile, and only three photos of the actresses are taken frontally. It is possible to study the difference between the main characters in costume and in street clothes, and to consider the theatre's power to transform.

\section{Illustrative Drawings}

Five drawings are placed in a half circle around the private photos. Where the lines in the drawing are covered by a photo, new lines are drawn on the latter. The draughtsman has signed his name (O. Anderson), and the drawings seem to be impressions from the performance. Let us start with the drawing at bottom right, which features a cradle that has no connection to the play, but only to the background story about the children that have been exchanged. At top right is a scene from a holy spring, where Hildur feels that she belongs in the upper world; at top center is a hall where the big wedding party in the underworld is held; at top left is a hall in Ljungby Castle; and at bottom left are a couple of brownies in the underworld. At bottom center is a photo of an unnamed young actress and the handwritten text "Ljungby Horn. Tournee I 894-I895" followed by “(direction A. Ranft.)” repeated twice. The last item might have been written by Ranft himself. In the lower part of the montage are two flower stalks serving as ornaments, with two fairy-tale figures on the top. The drawings were probably of more interest for a person who had seen the production than a person wishing to learn about it. There is no indication that they were in colour in the original version. It seems that the montage was better suited as a souvenir than as a marketing tool. The drawings do not promote the actors; rather, they consist of pictures of the milieu where the play takes place.

25 Rosenqvist, Mittsvenska scener, 244. 


\section{Remediation}

In her book, Anna Dahlgren uses Jay David Bolter and Richard Grusin's concept of remediation. A medium is defined by its relations to other techniques for representation, and a medium is defined as "that which remediates [...] appropriates the techniques, forms, and social significance of other media." New media remediates old, but old remediates new as well. ${ }^{26}$ This concept is useful in analyzing this montage.

Bolter and Grusin's point of departure is contemporary new media, thus they find that it is a "lens through which we can view the history of remediation." ${ }^{27}$ Even if it is a new object the "act of remediation, however, ensures that the older medium cannot be entirely effaced; the new medium remains dependent on the older one in acknowledged or unacknowledged ways." ${ }^{28}$

The viewer has to combine three layers, namely, the photo of the ensemble, the single photos of the actors, and the drawings, to obtain a view of the performance. There are also connections to the live performance and to the actors' previous stage appearances. The emblematic figures from the folk-tale tradition are linked to oral history, narration, and singing. The actors in street clothes suggest their potential, as actors, for enacting other parts in new productions. In the example of the montage, the picture over the words Ljungby horn can be seen as remediating, whereby old and new forms are joined in a new form, photography, which finally places all the different parts on the same level. The process could be compared with Bolter and Grusin's description about how a viewer of a collage "oscillates between looking at patches of paper and paint on the surface of the work and looking through to the depicted objects as if they occupied a real space beyond the surface." ${ }^{29}$ Through the process of remediation, a wholeness stands forward that makes it possible for the viewer to examine the details and to assimilate the whole image. And I would also

\footnotetext{
${ }^{26}$ Dahlgren, Ett medium för visuell bildning, I 2.

27 Jay David Bolter and Richard Grusin, Remediation: Understanding New Media (Cambridge: MIT Press, I999), 2 I.

${ }_{28}$ Bolter and Grusin, Remediation, 47.

29 Bolter and Grusin, Remediation, 4I.
} 
argue that image could be expand with connections to the viewers' memories from the performance and the actors' previous appearances. The acts of viewing are different if the viewer has seen the performance or not.

Even if the use of this montage and the photo thereof is unknown, it can be seen as a mark of the importance of the production. Theatre's relation to other media is complicated; in the early days of film, actors were often subject to contractual restrictions on their appearance in films. This was probably based on the fear that audiences would be satisfied by seeing the actor on film and thus neglect to visit the theatre.

Theatre photographs of performances did not enjoy a longterm market, but photos of actors attained enormous popularity, based on the development of the production of visiting cards as well as the decreasing cost and increasing professional quality of photographs. Elizabeth Anne McCauley highlights the French photographer Nadar, who, for example, photographed the actress Sarah Bernhardt. However, when he made photos of selected actors and singers from the Comédie Française and the Opera, he did not take role photos, but photographed them in street clothes. ${ }^{\circ}$ Nevertheless, in both France and Sweden the most successful celebrity photos were those of actors in costume, associated with a role. In Paris, successful photographers located their ateliers in the same quarter as the theatre and entertainment district. ${ }^{3 \mathrm{I}}$ The process of how and where the photographs were sold in Sweden has not been fully researched, but they were sold by booksellers, art shops, and directly by the photographers' ateliers. ${ }^{32}$ Some actors' archives, such as those of Anders de Wahl or Tore Svennberg, include a number of both visiting cards and postcard photos. These were also used for sending messages to admirers, autographed over the lower part of the photo, as well as to theatre managers

$3^{\circ}$ Elizabeth Anne McCauley, Industrial Madness: Commercial Photography in Paris $1848-I 87 I$ (New Haven and London: Yale University Press, I994), I46.

${ }^{31}$ McCauley, Industrial Madness, 78.

${ }^{2}$ Söderberg and Rittsel, Den svenska fotografins historia, 45. 
and colleagues. ${ }^{33}$ Laurence Senelick points out that the photographs were distributed even among people who never got the chance to see them perform live. ${ }^{34}$ Joel Anderson finds that the actor portraits "could circulate beyond the parameters of theatre spectatorship, and become emblems for individual worship: buyable, collectable, ownable images, fostering fascination for the figure of the celebrity actor." 35 Here is a separate media system, a sort of star system that has a number of similarities with the distribution of photo cards featuring Hollywood's movie stars in the twentieth century. The term "parasocial interaction" can be used here when describing the star system of the theatre. ${ }^{36}$ In the beginning of the twentieth century, when actors were scheduled to give guest performances, they were often asked to send their photos in advance to be used as marketing tools. ${ }^{37} \mathrm{~A}$ long time passed before theatrical photographs were published in newspapers. The first forms of illustration used along with reviews c.I900 were drawings or satirical sketches, which could be used to emphasize some typical aspect of the actors' style or even the interplay between actors. When photos were first published, they included only separate photos of the actors, often in street clothes..$^{8}$

\section{Conclusion}

There is an internal connection between the various layers in the montage that combine to compose the object. Individual elements are connected to the production in different ways, based as well

33 Teatersamlingarna (Theatre collections), Statens musikverk (Swedish Performing Arts Agency), Stockholm.

34 Senelick, "Early Photographic Attempts," 255.

35 Anderson, Theatre and Photography, 45.

${ }^{6}$ Thomas Baker used the term when studying the nineteenth-century culture of literary celebrities; Andreas Nyblom "Mediernas livrustkammare: Nordiska museet och berömmelsens materialitet" in I 80o-talets mediesystem, eds. Jonas Harvard and Patrik Lundell (Stockholm: Kungliga biblioteket, 20IO), I 80.

37 Letter from Nicken Rönngren to Pauline Brunius, August 8, I9 19, archive of Svenska Teatern, Svenska litterära sällskapet i Helsingfors.

${ }^{8}$ Curt Isaksson, Pressen på teatern: Teaterkritik $i$ Stockholms dagspress I890-I94I (PhD diss., Stockholm: Stiftelsen för utgivning av teatervetenskapliga studier, I987), I04-I09. 
on the status of different techniques and developments of that time. Together, they construct, via a remediating process, a wholeness that differs depending whether or not the viewer knows about or has seen the performance. The layers employ different techniques; even the two photo layers differ in terms of technique, costume, and collective and individual objects. The handwritten text items place the montage in conjunction with a specific theatre tour; without the text we should have great difficulty determining the relationship between the layers.

In the montage, several aspects of the production are visible: the original folk tale, the performance, the stage design, and the individual actors, prepared to take part in new productions. Together, they build up an image that functions as a souvenir of the performance.

\section{References}

Anderson, Joel. Theatre and Photography. Basingstoke: Palgrave Macmillan, 20I 5.

Assmann, Aleida. Cultural Memory and Western Civilization. Cambridge and New York: Cambridge University Press, 2013.

Balme, Christopher B. The Theatrical Public Sphere. Cambridge: Cambridge University Press, 2013.

Bergman, Gösta M. Den moderna teaterns genombrott I890-I925. Stockholm: Bonniers, I966.

Bolter, Jay David, and Richard Grusin. Remediation: Understanding New Media. Cambridge: MIT Press, I999.

Dahlgren, Anna. Ett medium för visuell bildning: Kulturhistoriska perspektiv på fotoalbum I850-I950. Stockholm: Makadam, 20I3.

G. B. [signed], “Stora Teatern,” Göteborgs-Posten, May I I, I 893.

Isaksson, Curt. Pressen på teatern: Teaterkritik i Stockholms dagspress I 890-I 94 I. PhD diss., Stockholm: Stiftelsen för utgivning av teatervetenskapliga studier, 1987.

Jürgensen, Knut Arne. The Bournonville Tradition: The First Fifty Years, I 829-I 879. London: Dance Books, I997. 
Kragh-Jacobsen, Svend. "August Bournonville og den romantiske ballet." In Den kongelige danske ballet, edited by Svend KraghJacobsen and Torben Krogh, I93-335. Copenhagen: Selskabet till udgivelse af kulturskrifter, I952.

McCauley, Elizabeth Anne. Industrial Madness: Commercial Photography in Paris I848-I87I. New Haven and London: Yale University Press, I994.

Nyblom, Andreas. "Mediernas livrustkammare: Nordiska museet och berömmelsens materialitet." In I800-talets mediesystem, edited by Jonas Harvard and Patrik Lundell, I77-I99. Stockholm: Kungliga biblioteket, $20 \mathrm{IO}$.

Ranft, Albert. Albert Ranfts memoarer: Första delen. Stockholm: Norstedts, I928.

Rosenqvist, Claes. Mittsvenska scener: Härnösand, Sundsvall och det sena I800-talets landsortsteater. Umeå: Johan Nordlandersällskapet, I998.

Rutchatz, Jens. "Zeit de Theaters/Zeit der Fotografie: Intermediale verschränkungen.” In Theater und Medien: Grundlagen - Analysen Perspektiven: Eine Bestandsaufnahme, edited by Henri Schoenmakers et al., I09-1 I6. Bielefeld: Transcript, 2008.

Schechter, Joel, ed. "Back to the Popular Source: Introduction to Part I." In Popular Theatre: A Sourcebook, 3-II. London and New York: Routledge, 2003.

Senelick, Laurence. "Early Photographic Attempts to Record Performance Sequence." Theatre Research International 22:3 (I997): 25 5-264.

Söderberg, Rolf, and Pär Rittsel. Den svenska fotografins historia I840-I940. Stockholm: Bonnier Fakta, I983.

Wieselgren, Oscar. "Frans O. L. Hodell." Svenskt biografiskt lexicon. Accessed October 28, 20I6. https://sok.riksarkivet.se/ $\mathrm{sbl} /$ artikel/ı 3680 .

\section{Archives}

Brevsamlingarna (Collection of letters), Kungliga biblioteket/National Library of Sweden, Stockholm. 
Svenska teaterns i Helsingfor arkiv (Archive of Svenska teatern in Helsinki), Svenska litterära sällskapet i Helsinfors/Society of Swedish Literature in Finland, Helsingfors.

Teatersamlingarna (Theatre collections), Göteborgs stadsmuseum/ The Museum of Gothenburg.

Teatersamlingarna (Theatre collections), Statens musikverk/Swedish Performing Arts Agency, Stockholm. 
